\title{
PELELANGAN BARANG GADAI DALAM PERSFEKTIF ISLAM
}

\author{
Dewi Oktayani \\ Sekolah Tinggi Ilmu Ekonomi (STIE) Syari'ah Bengkalis \\ dewioktayani87@gmail.com
}

\begin{abstract}
Pawn is an alternative for people who experience economic problems but do not want to lose their valuable possessions. The pawn can be done in the pawnshop as well as other financial institutions that provide pawn services. In Islam, the pawn is known as Ar-Rahn, which is to hold one of the borrower's assets from the loan he received. In a sharia pawnshop, the auction system applies to customers, if the customer is unable to pay his debt after maturity. The sale of liens after maturity is legal. That, according to the purpose of the understanding of the nature of the pawning itself, that is, as a trustee of a debt to be fulfilled. If the debtor is unable to pay the debt, the pawned goods can be sold to pay the debt, by representing the seller to a fair and trusted person. Auction according to sharia must also be able to be accounted for in Islamic law, which is free from the elements of gharar, maisir, usury and bathil.
\end{abstract}

Keywords: Auctions, Pawn Goods, Islamic Perspectives.

\begin{abstract}
ABSTRAK
Gadai merupakan salah satu alternatif untuk masyarakat yang mengalami masalah ekonomi tetapi tidak mau kehilangan barang berharga yang dimiliki. Gadai bisa dilakukan dilembaga gadai maupun lembaga keuangan lainnya yang menyediakan jasa gadai. Dalam Islam, gadai dikenal dengan Ar-rahn yaitu menahan salah satu harta milik peminjam atas pinjaman yang diterimanya. Dalam pegadaian syariah sistem lelang berlaku bagi nasabah, apabila nasabah tersebut tidak mampu membayar utangnya setelah jatuh tempo. Penjualan barang gadai setelah jatuh tempo adalah sah. Hal itu, sesuai dengan maksud dari pengertian hakikat gadai itu sendiri, yakni sebagai kepercayaan dari suatu utang untuk dipenuhi harganya. Bila yang berutang tidak sanggup membayar utang maka barang gadai dapat dijual untuk membayar utang, dengan cara mewakilkan penjualnya kepada orang yang adil dan terpecaya. Lelang sesuai syariah juga harus dapat dipertanggung jawabkan secara syariat islam yaitu bebas dari unsur gharar, maisir, riba dan bathil.
\end{abstract}

Kata Kunci: Lelang, Barang Gadai, Perspektif Islam.

\section{PENDAHULUAN}

Dalam memenuhi kebutuhan sehari-hari, setiap manusia tidak lepas dari yang namanya uang. Uang digunakan untuk membeli atau membayar berbagai keperluan. Semakin besarnya kebutuhan atau semakin meningkatnya harga-harga barang kebutuhan tanpa diiringi dengan kenaikan pendapatan akan membuat kita 
membatasi atau mengurangi untuk membeli barang-barang yang tidak begitu penting. Namun jika ada keperluan yang sangat penting, maka akan dilakukan berbagai cara untuk memenuhinya termasuk dengan cara meminjam dari berbagai sumber dana.

Bagi masyarakat yang memiliki barang-barang berharga, kesulitan dana yang dialami dapat diselesaikan dengan menjual barang berharga yang dimiliki. Namun, kekurangannya adalah barang tersebut akan hilang dan tidak dapat dimiliki kembali. Untuk mengatasi hal tersebut, maka masyarakat bisa menggadaikan barang berharga yang dimiliki tanpa kekhawatiran akan kehilangan barang tersebut karena barang tersebut bisa ditebus kembali serta memperoleh dana untuk mengatasi kesulitan yang sedang dialami.

Secara umum pengertian usaha gadai adalah kegiatan menjaminkan barang-barang berharga kepada pihak tertentu, guna memperoleh sejumlah uang dan barang yang dijaminkan akan ditebus kembali sesuai dengan perjanjian antara nasabah dengan lembaga gadai (Kasmir 2003, 246). Dari pengertian tersebut, dapat dijabarkan bahwa usaha gadai memiliki ciri-ciri sebagai berikut: terdapat barang-barang berharga yang digadaikan; nilai jumlah pinjaman tergantung nilai barang yang digadaikan; dan barang yang digadaikan dapat ditebus kembali.

Barang berharga yang dijaminkan dapat ditebus kembali oleh masyarakat yang menggadaikan. Namun jika dalam kondisi masyarakat tidak mampu untuk menebus barang yang digadaikan, maka pihak penerima gadai berhak untuk melakukan pelelangan atas barang gadai tersebut. Sebagai Umat Islam dan lembaga yang berlandaskan hukum Islam, proses pelelangan harus juga sesuai dengan syari'at Islam. Tujuan penelitian ini adalah untuk mengetahui konsep gadai dalam persfektif Islam dan untuk mengetahui pelelangan barang gadai jika ditinjau dari persfektif Islam

\section{TELAAH LITERATUR}

\section{Konsep Gadai}

Definisi gadai secara umum diatur dalam Pasal 1150 Kitab Undangundang Hukum Perdata (KUH Perdata), yaitu: "Gadai adalah suatu hak yang diperoleh seorang kreditur atas suatu barang bergerak yang bertumbuh maupun tidak bertumbuh yang diberikan kepadanya oleh debitur atau orang lain atas namanya untuk menjamin suatu hutang, dan yang akan memberikan kewenangan kepada kreditur untuk mendapatkan pelunasan dari barang tersebut lebih dahulu daripada kreditur-kreditur lainnya terkecuali biaya biaya untuk melelang barang tersebut dan biaya yang telah dikeluarkan untuk memelihara benda itu, biayabiaya mana yang harus didahulukan".

Dari definisi gadai tersebut terkandung adanya beberapa unsur pokok, yaitu: Gadai lahir karena perjanjian penyerahan kekuasaan atas barang gadai kepada kreditur pemegang gadai; Penyerahan itu dapat dilakukan oleh debitur atau orang lain atas nama debitur; Barang yang menjadi obyek gadai hanya benda bergerak, baik bertubuh maupun tidak bertumbuh; Kreditur pemegang gadai berhak untuk mengambil pelunasan dari barang gadai lebih dahulu daripada kreditur-kreditur lainnya (Patrik dan Kashadi 2003, 13).

Gadai merupakan jaminan dengan menguasai bendanya sedangkan hak tanggungan merupakan jaminan dengan tanpa menguasai bendanya, gadai di 
Indonesia dalam praktek perbankan sedikit sekali dipergunakan, kadang-kadang hanya sebagai jaminan tambahan dari jaminan pokok yang lain. Hal demikian terjadi karena terbentur pada syarat inbezitstelling pada gadai, padahal si debitur masih membutuhkan benda jaminan tersebut (Patrik dan Kashadi 2003, 12).

Dasar hukum yang menjadi landasan gadai syariah adalah Al-Qur'an, hadist Nabi Muhammad SAW, Ijma, dan fatwa MUI. Hal dimaksud diungkapkan sebagai berikut: Al-Qur'an surah Al-Baqarah ayat 283 digunakan sebagai dasar dalam membangun konsep gadai yang berbunyi (Kemenag RI 2006):

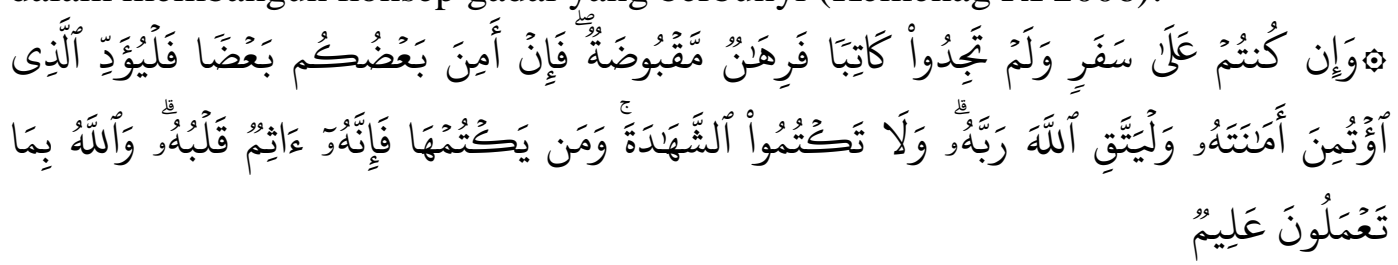

Artinya: “ Dan jika kamu dalam perjalanan (dan kamu melakukan muamalah tidak secara tunai) sedang kamu tidak memperoleh seorang penulis, maka hendaklah ada barang tanggungan yang dapat dijadikan sebagai pegangan (oleh yang mengutangkan), tetapi jika sebagian kamu mempercayai sebagian yang lain, maka hendaklah yuang dipercaya itu menunaikan amanat (utangnya) dan hendaknya ia bertakwa kepada Allah SWT, Tuhannya. Dan janganlah kamu menyembunyiak kesaksian, karena barang siapa menyembunyikannya, sungguh hatinya kotor (berdosa), Allah Maha mengetahui apa yang kamu kerjakan".

Hadist Aisyah RA., yang diriwayatkan oleh Imam Muslim, yang artinya: "Rasulullah Shalallahu Alaihi Wassalam pernah membeli makanan dari orang Yahudi dengan tempo (kredit) dan beliau mengagunkan baju besinya." (HR. Bukhari dan Muslim). Hadist dari Anas bin Malik RA., yang diriwayatkan oleh Ibnu Majah yang artinya: "Sesungguhnya Nabi Shalallahu Alaihi Wassalam pernah mengagunkan baju besinya di Madinah kepada orang Yahudi, sementara Beliau mengambil gandum dari orang tersebut untuk memenuhi kebutuhan keluarga Beliau." (HR. Al-Bukhari). Hadist dari Abu Hurairah yang diriwayatkan oleh Imam Al-Bukhari, yang artinya: "Nabi Muhammad SAW. bersabda: kendaraan dapat digunakan dan hewan ternak dapat pula diambil manfaatnya apabila digadaikan. Penggadai wajib memberikan nafkah dan penerima gadai boleh mendapatkan manfaatnya". Hadist riwayat Abu Hurairah RA, yang artinya: "Barang agunan tidak boleh disembunyikan dari pemilik yang mengagunkan baginya risiko dan hasilnya".

Ijma, Ulama menyepakati kebolehan status hukum gadai. Hal dimaksud berdasarkan pada kisah Nabi Muhammad SAW., yang menggadaikan baju besinya untuk mendapatkan makanan dari seorang yahudi. Para ulama juga mengambil indikasi dari contoh Nabi Muhammad SAW tersebut, ketika beliau beralih dari yang biasanya bertransaksi kepada para sahabat yang kaya kepada seorang Yahudi bahwa hal itu tidak lebih sebagai sikap Nabi Muhammad SAW. yang tidak mau memberatkan para sahabat yang biasanya enggan mengambil ganti ataupun harga yang diberikan oleh Nabi Muhammad SAW. kepada mereka.

Fatwa Dewan Syariah Nasional Majelis Ulama Indonesia (Fatwa DSNMUI) menjadi salah satu rujukan yang berkenaan dengan gadai syariah, diantaranya dikemukakan sebagai berikut: 1) Fatwa DSN-MUI No: 25/DSNMUI/III/2002 tentang Rahn; 2) Fatwa DSN-MUI No: 26/DSNMUI/III/2002 tentang Rahn Emas; 3) Fatwa DSN-MUI No: 
09/DSNMUI/IV/2000 tentang Pembiayaan Ijarah; 4) Fatwa DSN-MUI No: 10/DSNMUI/IV/2000 tentang Wakalah; dan 5) Fatwa DSN-MUI No: 43/DSNMUI/VIII/2004 tentang Ganti Rugi.

Perjanjian akad gadai dipandang sah dan benar menurut syariat Islam harus memenuhi syarat dan rukun yang telah diatur dalam hukum Islam. Adapun syarat dan rukun gadai adalah sebagai berikut: Rahin dan Murtahin, Sighat, Marhun Bih (utang), Marhun (barang jaminan) dan syarat kesempurnaan Rahn (pemegang barang).

Secara garis besar sifat-sifat gadai adalah sebagai berikut: Gadai adalah hak kebendaan; Hak gadai bersifat accessoir; Hak gadai tidak dapat dibagi-bagi; Hak gadai adalah hak yang didahulukan; Benda yang menjadi obyek hak gadai; Hak gadai (Patrik dan Kashadi 2003, 13).

\section{Konsep Lelang}

Lelang termasuk salah satu bentuk jual beli, akan tetapi ada perbedaan secara umum. Jual beli ada hak memilih, boleh tukar menukar dimuka umum dan sebaliknya, sedangkan lelang tidak ada hak memilih, tidak boleh tukar menukar dimuka umum, dan pelaksanannya dilakukan khusus dimuka umum (Ahmad 2004, 3). Lelang merupakan usaha untuk mengembalikan pinjaman yang tidak bisa dilunasi sampai batas tertentu. Usaha pelunasan ini dilakukan dengan cara menjual barang jaminan tersebut kepada umum.

Lelang sesuai syariah juga harus dapat dipertanggung jawabkan secara syariat islam yaitu bebas dari unsur gharar, maisir, riba dan bathil. Istilah yang digunakan adalah istilah yang berlaku pada POGS, misalnya barang jaminan adalah marhun, nasabah adalah rahin, serta istilah lainnya. Pengertian lelang secara syariah adalah proses penjualan marhun sebagaimana dijelaskan menurut fatwa DSN no.25/DSN-MUI/III-2002 butir kedua nomor 5a dan 5b yang menjelaskan tentang melelang barang dan penjualan marhun. Misalnya sebagai berikut: Penjualan marhun: 1) apabila jatuh tempo, Murtahin harus memperingatkan Rahin untuk segera melunasi utangnya, 2) apabila rahin tetap tidak dapat melunasi hutangnya, maka Marhun dijual paksa/dieksekusi melalui lelang sesuai syariah (DSN 2002).

Proses pelelangan dilakukan secara bertahap. Apabila telah jatuh tempo dan rahin tidak mampu untuk membayar, maka murtahin haruslah memberikan peringatan terlebih dahulu kepada rahin agar menunaikan kewajibannya. Namun, jika ternyata rahin tetap tidak mampu membayar hutangnya, maka murtahin berhak untuk menjual atau melelang barang jaminan (marhun) sebagai upaya untuk melunasi hutang rahin kepada murtahin.

Abu Hanifah berpendapat bahwa tidak boleh bagi yang menerima gadai menjual barang gadai yang diterimanya, tetapi boleh dijual dengan syarat setelah datang masa dan tidak sanggup menebusnya, tetapi harus dijualkan oleh yang menggadaikan atau wakilnya dengan seizin Murtahin (yang menerima gadai). Jika yang menggadaikan tidak mau menjualnya, hendaklah yang menerima gadai memajukan tuntutan kepada hakim (Ash Siddieqy 1991, 402).

Di dalam al- Qur'an tidak ada aturan pasti yang mengatur tentang lelang, tetapi berdasarkan definisi lelang dapat disamakan (diqiaskan) dengan jual-beli dimana ada pihak penjual dan pembeli. Dimana pegadaian dalam hal ini sebagai pihak penjual dan masyarakat yang hadir dalam pelelangan tersebut sebagai pihak 
pembeli. Jual beli termaktub dalam Al-Qur'an Surat Al-Baqarah ayat 275 (Kemenag RI 2006):

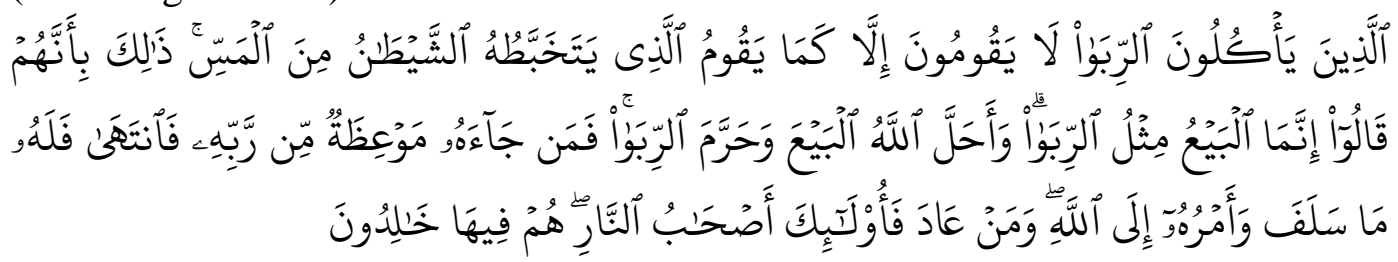

Artinya: "Orang-orang yang makan (mengambil) riba tidak dapat berdiri melainkan seperti berdirinya orang yang kemasukan syaitan lantaran (tekanan) penyakit gila. Keadaan mereka yang demikian itu, adalah disebabkan mereka berkata (berpendapat), sesungguhnya jual beli itu sama dengan riba, padahal Allah telah menghalalkan jual beli dan mengharamkan riba. Orang-orang yang telah sampai kepadanya larangan dari Tuhannya, lalu terus berhenti (dari mengambil riba), maka baginya apa yang telah diambilnya dahulu (sebelum datang larangan); dan urusannya (terserah) kepada Allah. Orang yang mengulangi (mengambilriba), maka orang itu adalah penghuni-penghuni neraka; mereka kekal di dalamnya".

Syariat Islam telah memberikan panduan dan kriteria umum sebagai pedoman pokok untuk mencegah adanya penyimpangan syariah dan pelanggaran hak, norma dan etika dalam lelang. Pedoman tersebut yaitu sebagai berikut: Transaksi dilakukan oleh pihak yang cakap hukum atas dasar saling sukarela ('an taradhin); Objek lelang harus halal dan bermanfaat; Kepemilikan/kuasa penuh pada barang yang dijual; Kejelasan dan transparasi barang yang dilelang tanpa adanya manipulasi; Kesanggupan penyerahan barang dari penjual; Kejelasan dan kepastian harga yang disepakati tanpa berpotensi menimbulkan perselisihan; Tidak menggunakan cara yang menjurus kepada kolusi dan suap untuk memenangkan tawaran (Anshori 2011, 125)

Pada umumnya lelang hanya ada dua macam yaitu lelang turun dan lelang naik, keduanya dapat dijelaskan sebagai berikut: Lelang turun, lelang turun adalah suatu penawaran yang pada mulanya membuka lelang dengan harga tinggi, kemudian semakin turun sampai akhirnya diberikan kepada calon pembeli dengan tawaran tertinggi yang disepakati penjual melalui juru lelang (auctioneer) sebagai kuasa si penjual untuk melakukan lelang dan biasanya ditandai dengan ketukan. Lelang naik, penawaran barang tertentu kepada penawar yang pada mulanya membuka lelang dengan harga rendah, kemudian semakin naik sampai akhirnya diberikan kepada calon pembeli dengan harga tertinggi, sebagaimana Lelang ala Belanda (Dutch Auction) dan disebut dengan lelang naik. (Anshori 2011, 125)

Berdasarkan Peraturan Menteri Keuangan No. 27/PMK.06/2016 tentang Petunjuk Pelaksanaan lelang, Bab II pasal 5 Lelang terdiri dari: Lelang eksekusi, adalah lelang untuk melaksanakan putusan atau penetapan pengadilan, dokumendokumen lain yang dipersamakan dengan itu, dan/atau melaksanakan ketentuan dalam peraturan perundang- undangan. Lelang noneksekusi wajib, adalah lelang untuk melaksanakan penjualan barang yang oleh peraturan perundang-undangan diharuskan dijual secara lelang. Lelang noneksekusi sukarela, adalah lelang atas barang milik swasta, perorangan atau badan hukum/badan usaha yang dilelang secara sukarela (Kemenkeu RI 2016). 


\section{PEMBAHASAN}

Berdasarkan ketentuan dalam Pasal 1150 dan pasal-pasal lainnya dari KUHPdt dapat disimpulkan sifat dan ciri-ciri yang melekat pada hak gadai, adalah Objek atau barang-barang yang dapat digadaikan adalah kebendaan yang bergerak, baik kebendaan bergerak yang berwujud maupun yang tidk berwujud (Pasal 1150, Pasal 1153 KUHPdt). Gadai merupakan hak kebendaan atas kebendaan atau barang-barang yang bergerak milik seseorang (Pasal 1152 ayat (3) juncto Pasal 528 KUHPdt), karenanya walaupun barang-barang yang digadaikan tersebut beralih atau dialihkan kepada orang lain, barang-barang yang digadaikan tersebut tetap dan selalu mengikuti kepada siapapun objek barang-barang yang digadaikan itu berada (droit de suite). Jika kebendaan atau barang-barang yang digadaikan hilang atau dicuri orang lain, maka kreditur pemegang gadai berhak untuk menuntut kembali. Hak gadai memberikan kedudukan diutamakan (hak preferensi) kepada kreditur pemegang hak gadai (penerima gadai) (Pasal 1133, Pasal 1150 KUHPdt). Gadai bersifat acessoir pada perjanjian pokok, seperti perjanjian pinjam-meminjam uang, utang piutang, atau perjanjian kredit (Pasal 1150 KUHPdt). Gadai mempunyai sifat tidak dapat dibagi-bagi (ondeelbaar), yaitu membebani secara utuh objek kebendaan atau barang-barang yang digadaikan dan setiap bagian daripadanya, dengan ketentuan bahwa apabila telah dilunasinya sebagian dari utang yang dijamin, maka tidak berarti terbebasnya pula sebagian kebendaan atau barang-barang digadaikan dari beban hak gadai, melainkan hak gadai itu tetap membebani seluruh objek kebendaan atau barangbarang yang digadaikan untuk sisa utang yang belum dilunasi (Pasal 1160 KUHPdt). Kebendaan atan barang-barang yang digadaikan harus berada di bawah penguasaan kreditur pemegang gadai (penerima gadai) yang memegang hak gadai atau pihak ketiga untuk dan atas nama pemegang hak gadai tersebut (Pasal 1150, Pasal 1152 KUHPdt).

Dalam hukum adat gadai di artikan sebagai menyerahkan tanah untuk menerima sejumlah uang secara tunai, dengan ketentuan si penjual (penggadai) tetap berhak atas pengembalian tanahnya dengan jalan menebusnya kembali (Muttaqien 2009, 106-107). Kepemilikan barang gadai tetap pada penggadai. Penerima gadai hanya berhak menahan barang gadai selama penggadai belum mampu untuk menebusnya.

Tanah atau harta akan dapat diperoleh kembali oleh penggadai dengan cara melunasi pinjaman atau sejumlah uang yang didapat dengan cara menjaminkan tanah atau harta tadi. Pihak penerima gadai juga wajib mengembalikan barang gadai tersebut jika sudah ditebus oleh penggadai.

Dalam Islam, gadai dikenal dengan Ar-rahn Ar-rahn adalah menahan salah satu harta milik si peminjam atas pinjaman yang diterimanya. Barang yang di tahan tersebut memiliki nilai ekonomis. Dengan demikian pihak yang menahan memperoleh jaminan untuk dapat mengambil kembali seluruh atau sebagian piutangnya. Secara sederhana. dapat dijelaskan bahwa rahn adalah semacam jaminan hutang atau gadai (Antonio 1999, 184). Jadi barang-barang yang bisa dijaminkan adalah barang-barang yang berharga dan laku untuk dijual. Barang yang dijaminkan haruslah memiliki nilai lebih tinggi dari jumlah hutang yang harus dibayar. Hal ini untuk menghindari risiko jika terjadi wanprestasi atau kredit macet. 
Adapun istilah-istilah yang di gunakan dalam perjanjian gadai menurut hukum islam adalah sebagai berikut: Pemilik barang (yang berhutang) atau penggadai diistilahkan dengan rahn. Orang yang memberi utang atau penerima gadai, diistilahkan dengan murtahin. Obyek atau barang yang di gadaikan, diistilahkan dengan marhun.

Dalam menjalankan transaksi rahn harus memenuhi syarat-syarat sebagai berikut: Syarat aqid, baik rahin dan murtahin adalah harus ahli tabarru' yaitu orang yang berakal, tidak boleh anak kecil, gila, bodoh, dan orang yang terpaksa. Serta tidak boleh seorang wali. Marhun bih (utang) syaratnya adalah jumlah atas marhun bih tersebut harus berdasarkan kesepakatan aqid. Marhun (barang) syaratnya adalah harus mendatangkan manfaat bagi murtahin dan bukan barang pinjaman.

Beberapa hal yang perlu diperhatikan dalam pelaksanaan ar-rahn antara lain: (1) Kedudukan barang gadai, selama ada di tangan pemegang gadai, maka kedudukan barang gadai hanya merupakan suatu amanat yang dipercayakan kepadanya oleh pihak penggadai. (2) Pemanfaatan barang gadai, pada dasarnya barang gadai tidak boleh diambil manfaatnya baik oleh pemiliknya maupun oleh penerima gadai. Hal ini disebabkan status barang tersebut hanya sebagai jaminan utang dan sebagai amanat bagi penerimanya. Apabila mendapat izin dari masingmasing pihak yang bersangkutan, maka barang tersebut boleh dimanfaatkan. Oleh karena itu agar di dalam perjanjian gadai itu tercantum ketentuan jika penggadai atau penerima gadai meminta izin untuk memanfaatkan barang gadai, maka hasilnya menjadi milik bersama. Ketentuan ini dimaksudkan untuk menghindari harta benda tidak berfungsi atau mubazir. (3) Resiko atas kerusakan barang gadai, ada beberapa pendapat mengenai kerusakan barang gadai yang disebabkan tanpa kesengajaan murtahin. Ulama mazhab Syafi'i dan Hambali berpendapat bahwa murtahin (penerima gadai) tidak menanggung resiko sebesar harga barang yang minimum. Penghitungan di mulai pada saat diserahkannya barang gadai kepada murtahin sampai hari rusak atau hilang. (4) Pemeliharaan barang gadai, para ulama' syafi'iyah dan hanabilah berpendapat bahwa biaya pemeliharaan barang gadai menjadi tanggungan penggadai dengan alasan bahwa barang tersebut berasal dari penggadai dan tetap merupakan miliknya. Sedangkan para ulama' Hanafiyah berpendapat lain, biaya yang diperlukan untuk menyimpan dan memelihara keselamatan barang gadai menjadi tanggungan penerima gadai dalam kedudukanya sebagai orang yang menerima amanat. (5) Kategori barang gadai, jenis barang yang bisa digadaikan sebagai jaminan adalah semua barang bergerak dan tak bergerak yang memenuhi syarat sebagai berikut: Benda bernilai menurut hokum syara'; Benda berwujud pada waktu perjanjian terjadi; Benda diserahkan seketika kepada murtahin. (6) Pembayaran atau pelunasan utang gadai, apabila sampai pada waktu yang sudah di tentukan, rahin belum juga membayar kembali utangnya, maka rahin dapat dipaksa oleh marhun untuk menjual barang gadaiannya dan kemudian digunakan untuk melunasi hutangnya. (7) Prosedur pelelangan gadai, jumhur fukaha berpendapat bahwa orang yang menggadaikan tidak boleh menjual atau menghibahkan barang gadai, sedangkan bagi penerima gadai dibolehkan menjual barang tersebut dengan syarat pada saat jatuh tempo pihak penggadai tidak dapat melunasi kewajibanya (Muhammad dan Sholikhul 2003, 54). 
Jumhur fukaha berpendapat bahwa orang yang menggadaikan tidak boleh menjual atau menghibahkan barang gadai. Sedangkan bagi penerima gadai diperbolehkan untuk menjual barang tersebut dengan syarat pada saat jatuh tempo pihak penggadai tidak dapat melunasi kewajibannya (Idris dan Abu 1990, 59).

Dalam pegadaian syariah sistem lelang berlaku bagi nasabah, apabila nasabah tersebut tidak mampu membayar utangnya setelah jatuh tempo. Penjualan barang gadai setelah jatuh tempo adalah sah. Hal itu, sesuai dengan maksud dari pengertian hakikat gadai itu sendiri, yakni sebagai kepercayaan dari suatu utang untuk dipenuhi harganya. Bila yang berutang tidak sanggup membayar utangnya sendiri dari orang berpiutang. Karena itu, barang gadai dapat dijual untuk membayar utang, dengan cara mewakilkan penjualnya kepada orang yang adil dan terpercaya. Sebelum dilakukan proses pelelangan barang gadai, pihak penerima gadai akan memberitahukan terlebih dahulu kepada pemilik barang gadai.

Jika terdapat persyaratan menjual barang gadai pada saat jatuh tempo, hal ini dibolehkan dengan ketentuan sebagai berikut: Murtahin harus terlebih dahulu mencari tahu keadaan rahin; Dapat memperpanjang tenggang waktu pembayaran; Kalau Murtahin benar-benar butuh uang dan rahin belum melunasi hutangnya, maka murtahin boleh memindahkan barang gadai kepada murtahin lain dengan izin rahin; Apabila ketentuan diatas tidak terpenuhi, maka murtahin boleh menjual barang gadai dan kelebihan uangnya dikembalikan kepada rahin (Muhammad dan Sholikhul 2003, 118).

Sebelum penjualan barang gadai dilakukan, akan dilakukan pemberitahuan terlebih dahulu kepada rahin. Pemberitahuan dilakukan dengan memberian surat pemberitahuan, melalui telepon, pengumuman dan sebagainya. Harga lelang disesuaikan dengan harga pasar. Jika harga barang melebihi dari hutang, maka murtahin akan mengembalikan sisanya kepada rahin, namun jika harga barang lebih kecil dari nilai hutang, maka rahin wajib untuk membayar kekurangannya.

Dalam sistematika lelang, penjual tidak diperkenankan terlebih dahulu menyebutkan harga barang yang dilelang, karena dikhawatirkan ada yang mendengar dari jauh dan mengira barang itu dihargai dengan nominal tersebut. Para pembeli dikumpulkan terlebih dahulu, lalu satu persatu ditanyai mengenai berapa harga yang selanjutnya atau siapa yang ingin membeli dengan harga yang lebih tinggi. Naik dan terus naik tinggi harga sampai pada penawar terakhir dan jatuhlah barang tersebut kepada sipenawar terakhir dengan harga yang ia kemukakan (Fatwa Al-Lajnah Ad-Da'imah).

Al-lajnah ad-daimah menjelaskan "seseorang yang menambahi harga barang yang dilelang padahal dia tidak bermaksud untuk membelinya, tindakan tersebut adalah haram, karena mengandung unsur penipuan terhadap pembeli lainnya. Sebab pembeli akan mengira atau meyakini bahwa orang tersebut tidak akan berani menambah harga melainkan karena memang barang tersebut seharga tersebut, padahal tidak demikian. Inilah yang disebut najsy yang dilarang oleh Rasulullah SAW. dengan larangan haram. Sebagaimana yang disebutkan dalam hadits yang diriwayatkan oleh Ibnu 'Umar Radhiyallahu 'Anhuma yang artinya: "bahwasannya Rasvilullah Shallallahu 'alaihi wa salam melarang najsy" (Muttafaqun 'Alaihi).

Najasyi adalah seseorang menambah atau melebihi harga temannya dengan memancing-mancing agar mau membeli barang milik temannya tersebut (Masjupri 2013, 111). Secara istilah najasyi memiliki beberapa bentuk misalnya, 
seseorang menaikkan harga pada saat lelang sedangkan dia tidak berniat untuk membeli, baik ada kesepakatan sebelumnya antara dia dan pemilik barang atau perantara, maupun tidak. Penjual menjelaskan kriteria barang yang tidak sesungguhnya. Penjual berkata,"harga pokok barang ini sekian"dalam penetapan harga, padahal dia berdusta (Ayub 2009, 105).

Juga diriwayatkan dalam hadis Abu Hurairah RA., pada perkataan Rasulullah SAW yang artinya: "janganlah kalian mencegah khalifah dagang sebelum masuk pasar. Jangan pula sebagian kalian membeli apa yang sedang dibeli orang lain. Jangan pula kalian saling najsy. Dan orang kota tidak boleh menjualkan barang orang dusun" (Muttafaqun 'Alaihi).

Lelang merupakan suatu bentuk jual beli dimana penjual menawarkan barang yang akan dijual kepada umum dengan menyebutkan harga barang. Disinilah pembeli akan saling menawar. Pembeli yang menawarkan harga yang paling tinggi, maka akan mendapatkan barang tersebut.

Harga sebuah komoditas (barang dan jasa) ditentukan oleh permintaan dan penawaran, perubahan yang terjadi pada harga berlaku juga ditentukan oleh terjadinya perubahan permintaan dan penawaran. Hal ini sesuai dengan hadist yang diriwayatkan dari Anas bahwasannya suatu hari terjadi kenaikan harga yang luar biasa di masa Rasullullah SAW, maka sahabat meminta nabi untuk menentukan harga pada saat itu, Dalam terminologi Arab yang maknanya pada harga yang adil adalah qimah al adl. Istilah qimah al adl (harga yang adil) pernah digunakan oleh Rasulullah SAW. dalam mengomentari kompensasi bagi pembebasan budak di mana budak ini akan menjadi manusia merdeka dan majikannya tetap memperoleh kompensasi dengan harga yang adil (Nasution, Mustafa dkk 2006, 160).

\section{KESIMPULAN}

Gadai merupakan kegiatan menjaminkan barang-barang berharga kepada pihak tertentu, guna memperoleh sejumlah uang dan barang yang dijaminkan akan ditebus kembali sesuai dengan nilai barang yang dijaminkan, dan akan ditebus pada saat jatuh tempo. Barang gadai sejatinya tidak boleh dimanfaatkan oleh penerima gadai tanpa seizin dari pemilik barang gadai. Karena pada hakikatnya kepemilikan barang gadai masih berada ditangan pemilik barang gadai. Barng gadai dipegang oleh penerima gadai hanya sebagai jaminan atas utang yang dimiliki oleh pemilik barang. Setelah jatuh tempo atau pemilik barang sudah mampu untuk menebs barangnya kembali, maka penerima gadai wajib untuk mengembalika barang gadai tersebut kepada pemiliknya. Namun jika dalam kondisi pemilik barang gadai tidak mampu untuk menebus barang gadai dan melunasi utangnya, maka penerima gadai berhak untuk menjual barang gadai dengan menginformasikan terlebih dahulu kepada pemilik barang gadai. Lelang merupakan usaha untuk mengembalikan pinjaman yang tidak bisa dilunasi sampai batas tertentu. Usaha pelunasan ini dilakukan dengan cara menjual barang jaminan tersebut kepada umum. Dalam sistematika lelang, penjual tidak diperkenankan terlebih dahulu menyebutkan harga barang yang dilelang, karena dikhawatirkan ada yang mendengar dari jauh dan mengira barang itu dihargai dengan nominal tersebut. Para pembeli dikumpulkan terlebih dahulu, lalu satu persatu ditanyai mengenai berapa harga yang selanjutnya atau siapa yang ingin membeli dengan 
harga yang lebih tinggi. Naik dan terus naik tinggi harga sampai pada penawar terakhir dan jatuhlah barang tersebut kepada sipenawar terakhir dengan harga yang ia kemukakan.

\section{DAFTAR PUSTAKA}

Ahmad, Aiyub. 2004. Fikih Lelang Perspektif Hukum Islam dan Hukum Positif. Jakarta: Kiswah.

Antonio, Muhammad Syafi'i. 1999. “Bank Syari'ah Suatu Pengenalan Umum” Jakarta: Tazkia Institute.

Anshori, Abdul Ghofur. 2011. Gadai Syariah Di Indonesia, Yokyakarta: Gajah Mada University Press.

Ash Siddieqy, Hasby. 1991. Hukum-Hukum Fikih Islam. Jakarta: PT Bulan Bintang.

Ayub, Muhammad. 2009. Understanding Islamic Finance. Jakarta: PT. Gramedia Pustaka Utama.

Dewan Syariah Nasional. 2002. Fatwa Dewan Syariah Nasional No. 25 Tahun 2002 tentang Rahn.

Fatwa Al-Lajnah Ad-Da'imah. 13/120-121. Dan Syarhul Buyu'.

Idris, Abdul Malik dan Abu Ahmadi. 1990. Terjemah Ringkas Fiqih Islam Lengkap. Jakart: Rineka Cipta.

Kasmir. 2003. Bank dan Lembaga Keuangan Lainnya, Cet. 7. Jakarta: PT. Raja Grafindo Persada.

Kementerian Agama RI. 2006. Al-Quran. Jakarta: PT. Karya Toha Putra.

Kementrian Keuangan RI. 2016. Peraturan Menteri Keuangan No.27/PMK.06/2016 tentang Petunjuk Pelaksanaan Lelang.

Masjupri. 2013. Buku Daras Fiqih Muamalah 1. Surakarta: FSEI Publishing.

Muhammad dan Sholikhul Hadi. 2003. Pegadaian Syari'ah. Jakarta: Salemba Diniyah.

Muttaqien, Dadan. 2009. Aspek Legal Lembaga Keuangan Syari'ah, cet.1. Yogyakarta: Safira Insani Press.

Nasution, Mustafa Edwin, dkk. 2006. Pengenalan Ekslusif Ekonomi Islam, Jakarta: Kencana.

Patrik, Purwahid dan Kashadi. 2003. Hukum Jaminan. Semarang: Fakultas Hukum Undip.

Rifa'i, Moh. 2002. Konsep Perbankan Syari'ah. Semarang: CV. Wicaksana.

Syafi'i, Rachmat. 2000. Fiqh Muamalah. Bandung: Pustaka Setia. 